\title{
Biological Nanosensors On Network for Diabetes Control With Alert Emission for Users
}

Nanosensores biológicos en red para el control de diabetes con emisión de alertas a usuarios

Nanossensores biológicos em rede para o controle de diabetes com emissão de alertas para os usuários

\author{
Edison Andres Quijano Suarez ${ }^{1}$ \\ Hector Felipe Hurtado Acosta ${ }^{2}$ \\ Gerardo Alberto Castang Montiel ${ }^{3}$
}

Received: June $1^{\text {th }}, 2019$

Accepted: August $5^{\text {th }}, 2019$

Available: September 16 $6^{\text {th }}, 2019$

How to cite this article:

E. A. Quijano Suarez, H. F. Hurtado Acosta, and G. A. Castang Montiel, "Biological Nanosensors On Network for Diabetes Control With Alert Emission for Users,"

Revista Ingeniería Solidaria, vol. 15, no. 3, 2019.

doi: https://doi.org/10.16925/2357-6014.2019.03.10

Artículo de investigación. https://doi.org/10.16925/2357-6014.2019.03.10

1 Universidad Distrital Francisco Jose de Caldas, Bogotá, Colombia

ORCID: https://orcid.org/0000-0002-5365-6025

2 Universidad Distrital Francisco Jose de Caldas, Bogotá, Colombia

ORCID: https://orcid.org/0000-0002-8097-757X

E-mail: hfhurtadoa@correo.udistrital.edu.co

3 Universidad Distrital Francisco Jose de Caldas, Bogotá, Colombia

ORCID: https://orcid.org/0000-0001-9788-5121 


\section{Abstract}

Introduction: This paper is the product of the research "Biological network nanosensors for diabetes control with the issuance of alerts to users", developed in the technological faculty of the Francisco José de Caldas District University carried out during 2018 and 2019.

Problem: Diabetes is a disease that affects most of the adult population and not having proper control can lead to health complications that lead to early deaths.

Objective: To propose a theoretical prototype for communication between a nano network and the applications that work to monitor networks, which issues an alarm to users who have diabetes and thus have better control of their disease.

Methodology: Research articles, books and forums published from 2010 onwards (some exceptions are found in the references) were used, along with official documentation of tools such as Netcool, Nagios and Pandora.

Results: 66 sources were found including papers, monographs, forums and others that complied with the research guidelines. In addition, numerous applications were found that can be implemented in the proposed theoretical prototype.

Conclusion: A theoretical prototype is proposed for communication between a nano network and an alarm management system for the end user. This prototype use current technologies and specialized tools.

Originality: The article presents an innovative theoretical prototype, designed to solve a problem in the health sector, that makes use of emerging technologies.

Limitations: The internet of nano-things, oriented to biological processes, is an emerging technology. At the time of writing this paper, there are no real prototypes or tools to simulate nano networks in conjunction with biotechnology.

Key Words: Nano-network, Nano-sensor, Nanotechnology, Nanoscience, Nano-medicine, Diabetes.

\section{Resumen}

Introducción: este artículo es el producto de la investigación "Nanosensores biológicos en red para el control de diabetes con emisión de alertas a usuarios", desarrollada en la facultad tecnológica de la Universidad Distrital Francisco José de Caldas durante los años 2018 y 2019.

Problema: la diabetes es una enfermedad que aqueja a la mayor parte de la población adulta, el no llevar un control adecuado puede generar complicaciones de salud que conllevan a una muerte temprana.

Objetivo: proponer un prototipo teórico de comunicación entre una nanored y las aplicaciones que funcionan para monitorear redes, el cual permita emitir alarmas a usuarios que posean diabetes y así llevar mejor control de su enfermedad.

Metodología: se usaron artículos de investigación, libros y foros publicados desde el 2010 en adelante (en las referencias se encuentran unas excepciones). Se utilizo documentación oficial de herramientas como Netcool, Nagios y Pandora.

Resultados: se encontraron 66 trabajos entre artículos, monografías, foros y demás que cumplían con el lineamiento de la investigación; además, se encontraron numerosas aplicaciones que se pueden implementar en el prototipo teórico propuesto.

Conclusión: se propone un prototipo teórico para la comunicación entre una nanored y un sistema gestor de alarmas para usuarios finales haciendo uso de tecnologías actuales y herramientas especializadas.

Originalidad: el artículo presenta un prototipo teórico innovador para solucionar una problemática en el sector de la salud haciendo uso de tecnologías emergentes. 
Limitaciones: el Internet de las nano cosas orientado a procesos biológicos es una tecnología emergente, en el momento en que se realiza el articulo no se cuenta con prototipos reales ni herramientas para simular nano redes en conjunto con la biotecnología .

Palabras clave: Nanored, Nanosensor, Nanotecnología, Nanociencia, Nanomedicina, Diabetes.

\section{Resumo}

Introdução: este artigo é produto da pesquisa "Nanossensores biológicos em rede para o controle de diabetes com emissão de alertas para os usuários", desenvolvida na faculdade tecnológica da Universidad Distrital Francisco José de Caldas, durante 2018 e 2019.

Problema: a diabetes é uma doença que afeta a maior parte da população adulta. Não manter um controle adequado pode gerar complicações de saúde e levar a uma morte precoce.

Objetivo: propor um protótipo teórico de comunicação entre uma nanorrede e os aplicativos que funcionam para monitorar redes, de forma que permita emitir alarmes aos usuários que tenham diabetes para que controlem melhor a doença.

Metodologia: foram usados artigos de pesquisa, livros e fóruns publicados a partir de 2010 (nas referências há algumas exceções). Utilizou-se documentação oficial de ferramentas como Netcool, Nagios e Pandora.

Resultados: foram encontrados 66 trabalhos, entre artigos, monografias, fóruns e outros que cumpriam com o alinhamento da pesquisa; além disso, encontrou-se numerosos aplicativos que podem ser implementados no protótipo teórico proposto.

Conclusão: propõe-se um protótipo teórico para a comunicação entre uma nanorrede e um sistema gerenciador de alarmes para usuários finais com uso de tecnologias atuais e ferramentas especializadas.

Originalidade: o artigo apresenta um protótipo teórico inovador para solucionar uma problemática no setor da saúde a partir do uso de tecnologias emergentes.

Limitações: a internet das nanocoisas orientada a processos biológicos é uma tecnologia emergente, quando o artigo é produzido não se conta com protótipos reais nem ferramentas para simular nanorredes em conjunto com a biotecnologia.

Palavras-chave: nanorrede, nanossensor, nanotecnologia, nanociência, nanomedicina, diabetes.

\section{INTRODUCTION}

There is currently great growth in the use of Nano-scale sensors for applications in all kinds of industries or services. These sensors are often connected through a network with the aim of responding to a common goal. This is a part of the new trend of the Internet of things, but on a Nanoscale. It is the Internet of Nano things that will form the network of Nano-sensors for their application in the field of health. According to studies by the World Health Organization, one in eleven people have diabetes in the world [1]. This is a complex social and cultural problem that generates day-today deaths at an early age and causes diseases that have complications of equal order or superior to cancer. This article is aimed at people interested in going into a deeper perspective of the topic of Nano-sensor networks as used in the area of 
health, however, the article may also be useful for people immersed in the world of technology and who wish to develop innovative ideas for a common benefit by implementing telematics in the field of disease prevention and care. It seeks to address the main issues that describe the usage of this technology and its possible implementation in everyday life. These topics are associated with the chemistry and physics of Nanoparticles, sensors, Nano-sensors, the basic notions of a Nanoscale network for relevant communication, a description of diabetes and the paths to its detection, as well as a prototype of theoretical integration in which the generation of alerts and notifications is allowed through the use of tools for analysis, management, and emission of information from Nano-sensors.

\section{DIABETES}

Diabetes, as it is popularly known, is a set of metabolic diseases characterized by elevated blood sugar levels. The name established by the medical community for this chronic and systematic disease is "diabetes mellitus" (DM). One of the multiple definitions established for this condition states that it is "a metabolic disorder of multiple etiologies, characterized by chronic hyperglycemia with disturbances in the metabolism of carbohydrates, fats, and proteins, resulting from defects in secretion and/or in the action of insulin" [2]. As mentioned by Boudina and Abel [3], DM is a metabolic disorder characterized by hyperglycemia, insulin deficiency or a resistance to it.

\subsection{Epidemiology}

There is a notable increase in the number of diabetic patients, as projected by the studies of the World Health Organization (OMS; by its acronym in Spanish). [4] estimates that by 2030, the number of people with diabetes will reach 370 million. The International Diabetes Federation (IDF) [5] goes even further, estimating that the number of adults to be affected will increase to 552 million by the year 2030, and currently the IDF [6] establishes that the global prevalence of prediabetes ranges from $6 \%$ to $14 \%$, and for Colombia that estimate, adjusted by age (20-79 years), is from 8 to $10 \%$.

These are indeed alarming figures if one takes into account that many of these citizens who suffer from this disease do not know or have not been correctly diagnosed with it due to the precarious and insufficient healthcare system of Colombia. As can be seen in the DANE projection [7], for the year 2018, the population of prediabetes in the national territory there will be 3.2 million adult pre-diabetic patients, of which 2.1 million are not diagnosed or treated (See Figure 1). Taking this and what was 
mentioned by Aschner [8] in the article entitled "Epidemiology of diabetes in Colombia" into account, it can be established that this disease is among the first five causes of death in Colombia.

Estimated number of subjects with prediabetes in Colombia 2018

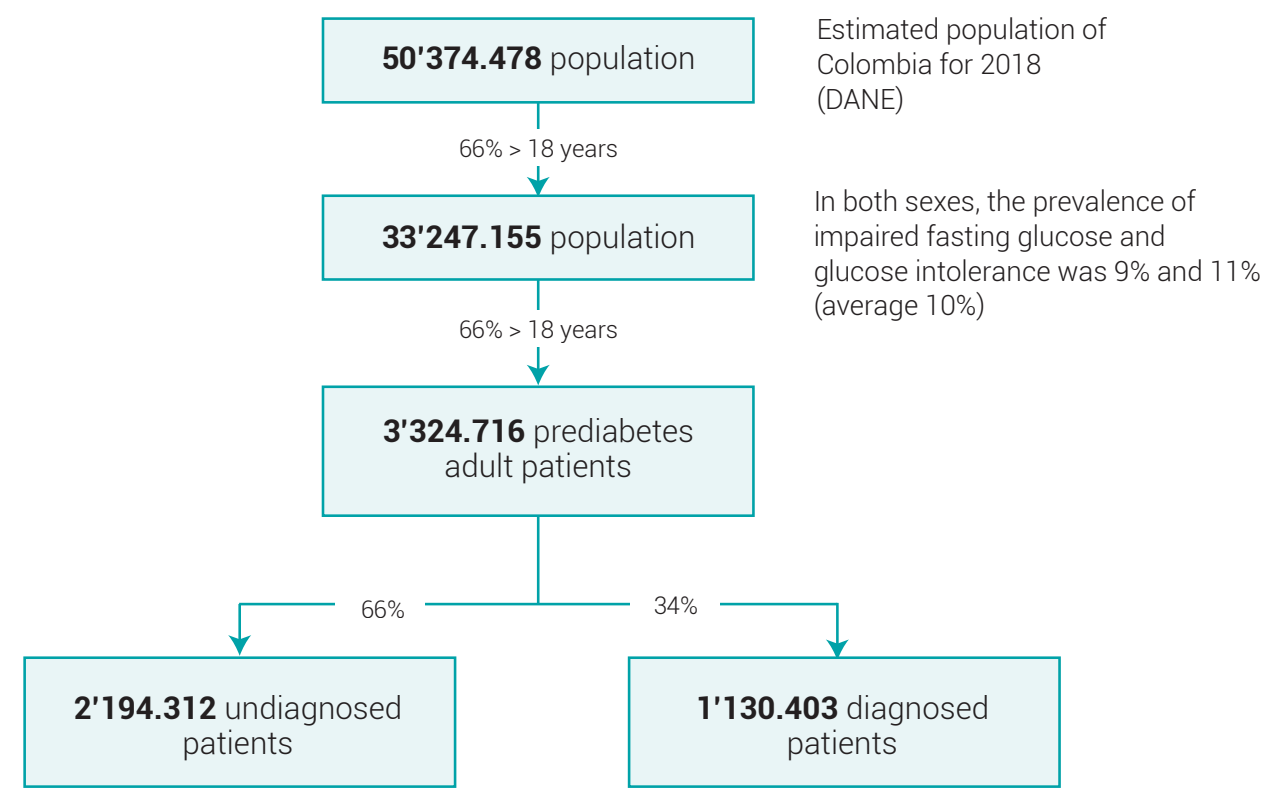

Figure 1. Estimation of number of prediabetes in Colombia. Source: [9]

\subsection{Classification of the DM}

In order to speak about classification, we will have to take into account the one given by Ojeda and Davila [10], which establishes that there are two classifications. The first one corresponds to the $\mathrm{WHO}$ and only recognizes three types of diabetes (type I, type II and gestational) and the second, proposed by the American Diabetes Association (ADA) in 1997 differentiates between 4 types of DM (See Table 1). 
Table 1. Classification of the diabetes mellitus.

\begin{tabular}{ll}
\hline \multicolumn{1}{c}{ Type } & \multicolumn{1}{c}{ Characteristics } \\
\hline I Insulin dependent & Absolute insulin deficiency of community or idiopathic mediation. \\
\hline II Not insulin dependent & $\begin{array}{l}\text { Begins during the adult stage due to insulin resistance or relative deficiency. Here } \\
\text { the body does produce insulin, but, it does not produce enough, or it cannot take } \\
\text { advantage of the one produced by itself and the glucose is not thoroughly distributed } \\
\text { in the body. }\end{array}$ \\
\hline III Gestational & $\begin{array}{l}\text { It is related to disorders in the mother and the death of the fetus or macrosomia at } \\
\text { the time of birth as the product of an abnormal size caused by increased glucose } \\
\text { levels. }\end{array}$ \\
\hline IV Other types & $\begin{array}{l}\text { Includes patients with genetic defects that modify the biological action of insulin } \\
\text { at the receptor or post-receptor level or pancreatic pathologies due to drugs, toxic } \\
\text { agents or infectious agents. }\end{array}$ \\
\hline
\end{tabular}

Source: [10]

\section{INTERNET OF NANO-THINGS}

This section describes the concept of the Internet of Things (IOT) with a focus on Nano-things as a prerequisite for the rest of the article. The loT concept, which currently can be applied in almost all areas that administer, manage, or interact with technology (and in some cases even the elements that do not involve it) "integrates all kinds of intelligent devices, including ubiquitous and autonomous, to create more attractive solutions for people and markets" [11]. Although there is no single or universal definition on this subject, it is understood as one of the most generalized and the one that best covers the concept of network object connectivity:

The loT is an intelligent network that connects all things to the Internet in order to exchange information and communicate through information detection devices in accordance with agreed protocols. [12].

Along with this, we can also mention a comprehensive definition in this regard which states:

The Internet of Things (IOT) is a framework in which all things have representation and presence on the Internet. More specifically, the Internet of Things aims to offer new applications and services that serve as a bridge between the physical and the virtual world, in which 'machine-to-machine' communications (M2M) represent the basic communication that allows the interactions between things and applications in the cloud. [13]. 


\subsection{Internet of the Nano-things}

The Internet of nano-things (IONT) is one of the new branches that have emerged with the idea of promoting technological advances around the generation of hardware devices at increasingly reduced scales; this is established under the concept of maintaining the connectivity trend focused on the Internet of Everything (IoE) and the IOT. These devices operate with the same logic as their full size counterparts, but their functions are established to provide support to different tasks of nature and human health; such as the operation of networked devices to provide treatment to DM directly within the organism.

\subsubsection{Purpose of IoNT}

If we take into account that the IONT is based on the use of nanotechnology for the hardware that will work in a network, it is possible to affirm that the IONT is a scenario where animals, people or objects are all connected or have some unique identifiers [14], allowing these to work together as a whole.

To understand the purpose of the IONT it is necessary to understand what this concept entails. For this, the main definitions on the subject are reflected below. The first definition to be discussed suggests that:

The Internet of Things (IOT) is a network of intelligent things/devices connected to the Internet that can communicate with each other and with human beings and that have brought enormous benefits to modern society [...] The IONT is based on the use of nanomachines, small components capable of performing simple tasks of processing, detection, and control that are used for the development of Nano-processors, $\mathrm{Na-}$ no-memories, Nano-bots, and Nano-watches. [15].

The proposal in the article entitled "A Tolerant Approach to Interruptions for the Security of the Internet of Things" of the year 2014, expresses that:

The Internet of Things (IOT, Internet of Things) is an emerging paradigm that seeks the interconnection of any object capable of having a part of electronics, favored by the miniaturization of components. [16]. 
Raul and Sarwade [17], in the article entitled "Study of environmental effects on the connectivity of the molecular communication-based Internet of Nano things" of the year 2016, define it as:

This is a futuristic network where individual Nano-objects perform simple calculations, communication, detection and action to perform intricate functions.

Considering these definitions, we can infer that the IoNT is the "extension of IoT in which it incorporates Nano-sensors in multiple objects in conjunction with the use of Nano-networks ... That is, the purpose is the ability to interconnect different types of devices developed at a Nano-scale in a communications network "[18], all focused on establishing a functionality around the collection of data and the performance of tasks in places of difficult access.

The following figure (See Figure 2) illustrates the interconnection operation that is established between the different elements that make up a network of this type. The Nano-sensors are connected to each other through Nano-networks, all with the purpose of obtaining important information within areas of difficult access. The Nanosensors in the body of a human being could collect and transmit signals to each other that contain crucial information for the treatment of DM. As such, these elements work by analyzing the levels of glucose in the blood, processing and transmitting information to normal sized devices, providing alerts about possible problems or alterations of the disease.

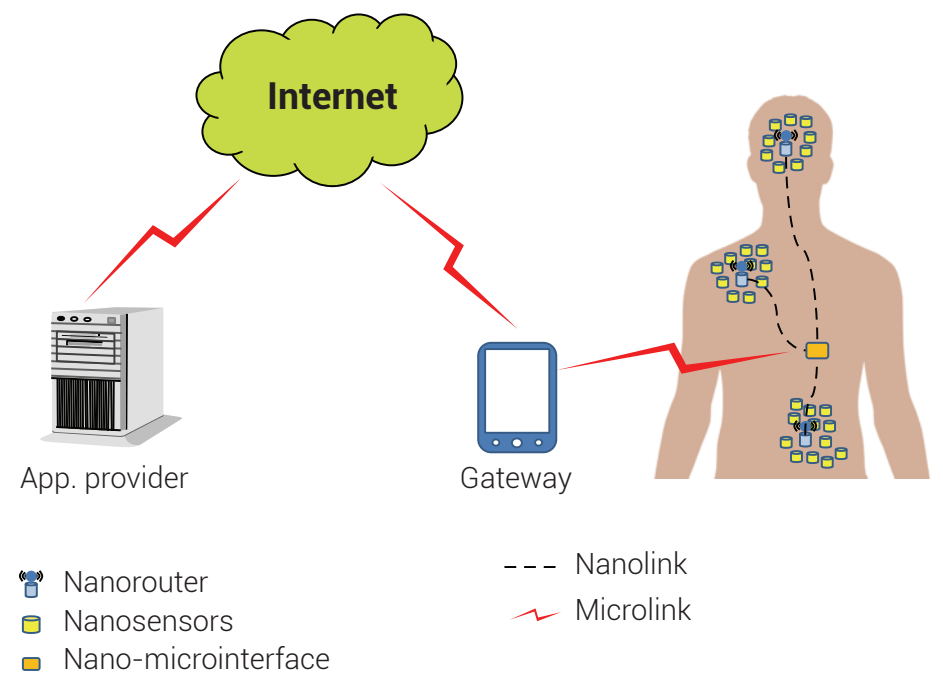

Figure 2. Functioning of loNT.

Source: [19] 


\subsection{Internet of the Bio-Nano-Things}

When understanding the concept of IoNT and understanding the purpose of this document (to demonstrate a model which allows sending signals of the status and treatment of DM in the organism), it is necessary to speak of sensors that behave in an adequate way within the organism of the living being. Therefore, the concept of the Internet of the Bio-Nano Things (IoBNT), as a solution to this branch, focuses on medicine and technology. The definition of IoBNT given by Akyildiz, Pierobon, Balasubramanian and Koucheryavy [20], in the article "The internet of Bio-Nano things" is:

Within the scope of the loBNT, Bio-Nano Things is defined as basic structural and functional units that operate and interact within the biological environment. It is expected that Bio-Nano Things, from biological cells, and enabled by synthetic biology and nanotechnology, perform tasks and functionalities typical of integrated computing devices in the IOT, such as detection, processing, interaction and interaction with each other.

These bio-nanodevices must be designed from biochemical molecules or by re-engineering existing biological systems [21] [22], so much so that this design is based on biological cells as part of the substructure of bio-nano things. Although these devices have great potential in the field of medicine and technology, they have a disadvantage; "having a small size these devices limit their computational and storage capacity, which in turn implies that one requires many nanodevices to work cooperatively in a given task" [23].

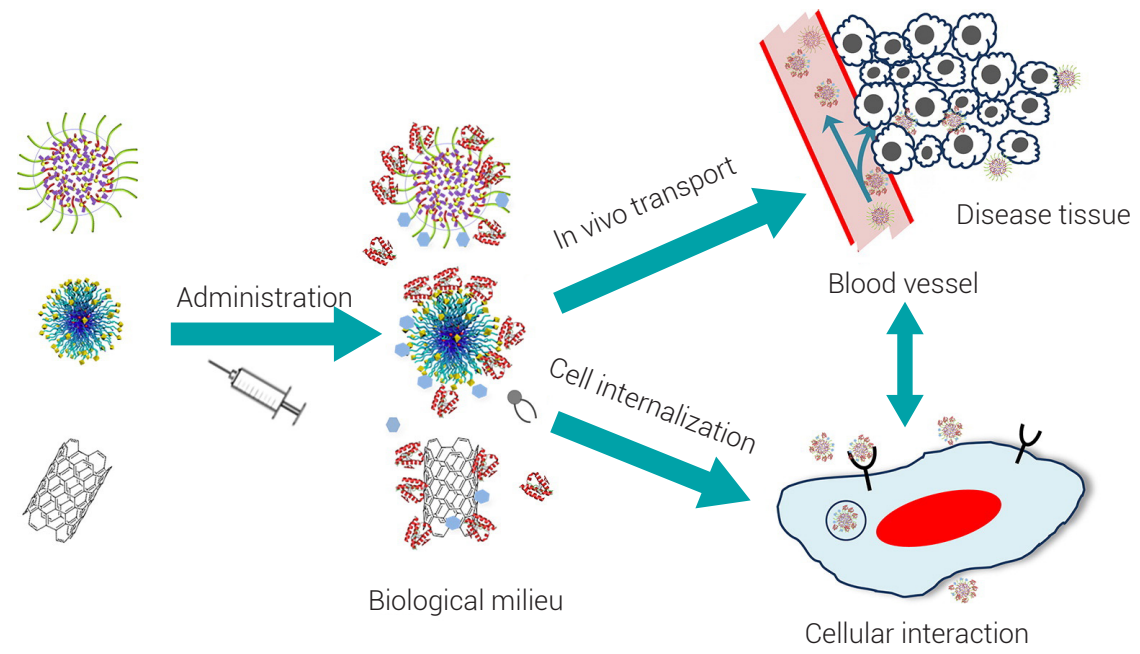

Figure 3. Elements of Bio-Nano interface.

Source: [24] 
In the figure above (See Figure 3), we observe some of the particles of the IOBNT architecture, represented as a cellular interaction, and their respective comparison in terms of the elements or components that make up the basic structure of an electronic interface of IoBNT. We can also see, in the table below, a series of areas in which the applicability of the IOBNT can be evidenced.

Table 2. Principal applications of the loBNT.

\begin{tabular}{ll}
\hline \multicolumn{1}{c}{ Application } & \multicolumn{1}{c}{ Definition } \\
\hline Detection & $\begin{array}{l}\text { The Bio-Nano Things collect information of the human body to } \\
\text { detect any problem and transmit it to an external health center } \\
\text { through the Internet. }\end{array}$ \\
\hline Control of intra-corporal connectivity & $\begin{array}{l}\text { Performs a monitoring of the nervous system and the endocrine } \\
\text { system through the Bio-Nano Things, to detect and correct failures } \\
\text { in communication between internal organs. }\end{array}$ \\
\hline Medication & $\begin{array}{l}\text { The Bio-Nano Things release medicine according to the needs of } \\
\text { the organism, for example, insulin for diabetics }\end{array}$ \\
\hline Control and cleaning of the environment. & Monitoring, control and reversion of pollution. \\
\hline
\end{tabular}

Source: [25]

\section{BIOLOGICAL NANO-SENSORS}

In this section of the article, the aspects corresponding to definitions and key concepts in understanding the functioning of biological Nano-sensors, as well as their applicability for treatments and verification of DM status, are addressed.

\subsection{Nano-science and Nano-technology}

Many definitions circulate on the web for Nano-science and Nano-technology and, like everything that appears on the Internet, should be interpreted with caution. As Jose Martin comments [26] in his dissemination, "The greatness of the small" expresses that nanoscience is the science of the infinitely small. This is not strictly true, since this definition responds better, for example, to the type of studies that high energy physics deals with, that works with protons, neutrons or even their constituents; quarks. Other people think that nanotechnology tries to reduce the size of objects to unsuspected limits. We will see that this is not completely accurate either since nanotechnology needs different manufacturing techniques, based on other concepts. Along with this definition, you can also analyze the concept of Jose Martin, Carlos Briones, Elena Casero and Pedro Serena [27], in which they state that sometimes, the 
word nanotechnology refers to the construction of devices and robots like the ones we have in our world but of very small dimensions. This, too, is an error. The problems presented by the definition of these terms are related to the fact that neither Nanoscience nor nanotechnology were born as closed disciplines, but both are fields of knowledge that have been built in parallel with the appearance of new discoveries and that, in fact, we do not know where they will come from [27]. The best definition of nanotechnology is that which expresses:

Nano-technology is the study, design, creation, synthesis, manipulation, and application of materials, devices, and functional systems through the control of matter at a Nano-scale, and the exploitation of phenomena and properties of matter at the Nano-scale. [28].

Nano-technology alone is a field that can help solve the urgent problems we have in the world, such as the use of renewable and alternative energy sources, the climate changes that are approaching, the use of drinking water, the development of agriculture and the creation of sustainable development modes [29]. Together with this, nanotechnology presents a new era in which science, technology, and society will be transformed [30]. Nanoscience, as such, will provide us with a field of action with greater potential for humanity by attacking health-focused problems such as DM, achieved by creating nanoscale devices equal to a length 80000 times smaller than the diameter of a human hair [31]; the scale of these devices (See Figure 4) is perfect for attacking the aforementioned health problems.

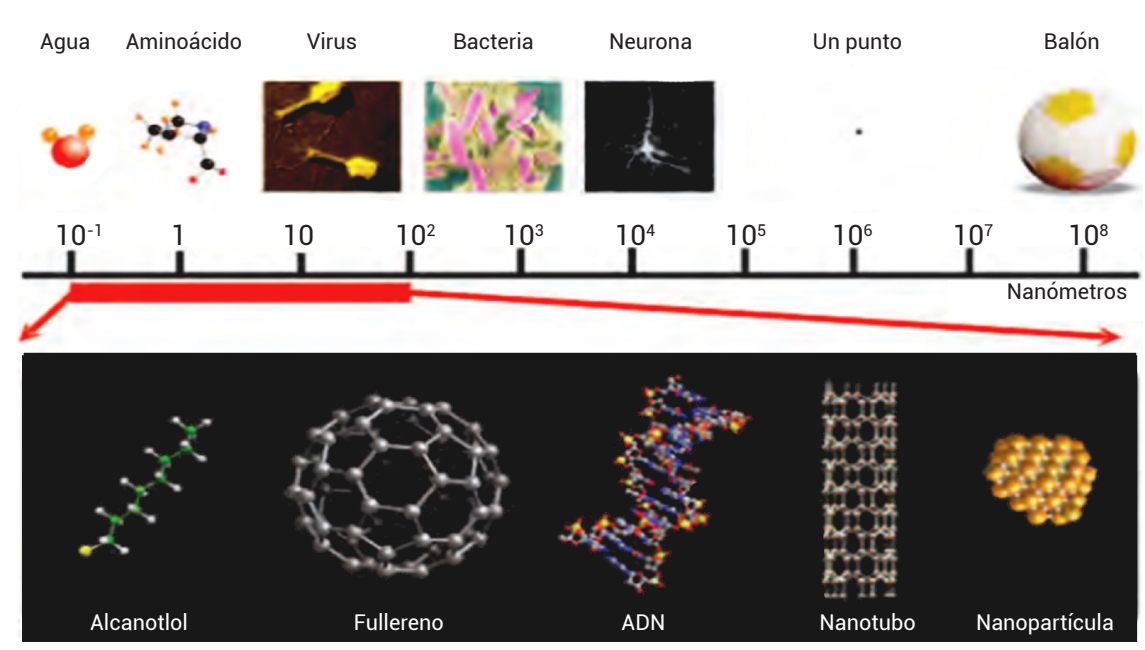

Figure 4. Actors of Nano-world. Different objects with their characteristic size. Source: [27] 


\subsection{Nano-medicine}

One of the most promising branches of nanotechnology is nanomedicine, which offers the possibility of diagnosing and treating diseases at the cellular and molecular level [32]. The main objective in this case is to develop tools to diagnose, prevent and treat diseases [33] difficult to manage, such as myocardial infarction, cancer, diabetes, kidney failure, the beginning of infection of the human immunodeficiency virus [34] and in neurodegenerative pathologies such as Alzheimer's and Parkinson's [35].

The components of nanomedicine can be conceptualized in three fundamental elements, as explained by the author Laura Lechuga [32]; Nano-diagnostics, Nanotherapy, and regenerative medicine:

Nano-diagnosis consists in the development of analysis and imaging systems to detect a disease or a cellular malfunction in the earliest possible stages both in vivo and in vitro. Nano-therapy aims to direct active Nano-systems containing recognition elements to act or transport and release drugs exclusively in cells or affected areas, in order to achieve more effective treatment, minimizing side effects. Regenerative medicine aims to repair or replace damaged tissues and organs by applying nanotechnological tools.

Nanomedicine is currently making great advances, among which include drug release Nano-systems, biochips, technological platforms, engineering Nano-devices, Nano-structures and biosensors [36], for monitoring, control, construction, repair, defense and improvement of all human biological systems, working at the molecular level through engineering devices and Nano-structures [37].

\subsection{Nano-biotechnology and diabetes}

Nanotechnology is one of the branches with the greatest projection of nanotechnology; which is mainly focused on integrating the concepts of biotechnology and nanomedicine through the use of Nano-state devices such as Nano-sensors. These elements have achieved significant advances in the diagnosis and treatment of some of the diseases that are difficult to manage.

To fully understand the concept of Nanobiotechnology, the author Laura Lechuga [38] raises two major areas of action: 
1. Application of tools, components, and processes of Nanotechnology to biological systems (which lately is being dominated by Nanomedicine) and developing tools to prevent and treat diseases in the human body when they are still in less advanced stages, which will lead to great advances in Diagnostics and Therapeutics.

2. Use of biological systems such as molds for the development of new products of nanometric scale (mainly electronic nanodevices).

The focus that will be given to nanotechnology in this document will be related to the first area of action which focuses on the development and application of the elements of nanotechnology to biological systems; in this case, to use them for monitoring of the DM.

The most commonly used devices are the Bio-Nano-sensors, which employ carbon nanotubes to measure the level of glucose in the blood. This provides an increase in the sensitivity in the limits of quantification, which are required for an improvement in the analysis [39]. The constant sampling of the patient can also be avoided.

For the development of these Nano-tubes, Professor Strano [40] proposes the creation of a layer of glucose oxidase enzyme on the surface of nanotubes suspended in water. Not only does this prevent the nanotubes from sticking and forming useless assemblies, but also gives them the functionality to act as a selective site where glucose binds and generates hydrogen peroxide. This generates a reaction with ferricyanide to modulate the structured electronics and the optical characteristics of the nanotube. Generating more glucose, the nanotube shines brighter, thus preventing the nanotube from touching the living cells [41].

These elements can also perform the required corrective measure by administering the exact dose of insulin required by the diabetic patient, which would be encapsulated in gold nanoparticles and would be released when the concentration of glucose in the blood increases; a concentration which would be monitored by Nanosensors [42] [43] [44].

\section{NETWORKS OF NANO-SENSORS}

For the development of a model that allows the generation of alarms emitted by Nano-sensors, a network that permits communication with the outside world is indispensable. A Nano-sensor network is a Nano-scale communication network that integrates nanodevices [45]. 
A Nano-network is a network of nanomachines. It expands the capabilities of a single nanodevice by providing a way to cooperate and share information. In general, the Nano-communication process is the exchange of information at the nanoscale based on any wired or wireless interconnection of nanomachines in a Nanonetwork [46].

\subsection{Architecture of the Network}

Talking about communication between nanodevices and external agents implies talking about a new network paradigm. This paradigm requires basic components to guarantee a reliable and effective architecture model. The basic components for a Nano-network architecture are independent of the type of application where they are implemented and are described as follows:

Table 3. Architectural devices of Nano-Network.

\begin{tabular}{ll}
\hline \multicolumn{1}{c}{ Component. } & \multicolumn{1}{c}{ Description. } \\
\hline Nano-nodes & $\begin{array}{l}\text { These are simple Nano-machines capable of processing data and transmitting them; } \\
\text { some examples are biological Nano-sensors within the human body. }\end{array}$ \\
\hline Nano-Routers & $\begin{array}{l}\text { Their main function is to add information that comes from the Nano-nodes and route it } \\
\text { as a normal router does. They can control the behavior of the Nano-nodes by means of } \\
\text { simple commands such as: off, sleep, read, value. }\end{array}$ \\
\hline $\begin{array}{l}\text { Nano-Micro Interface } \\
\text { device }\end{array}$ & $\begin{array}{l}\text { They work as hybrid devices that can be communicated at the nanoscale using Na- } \\
\text { no-networks or traditional networks. Their main characteristic is that they are responsi- } \\
\text { ble for transmitting information from the Nano-routers at a micro scale and vice versa. }\end{array}$ \\
\hline Gateway & $\begin{array}{l}\text { It allows the management and control of the Nano-network through the Internet, for } \\
\text { example, a Nano-network can send information to an application through a Nano-mi- } \\
\text { cro interface that is controlled by a gateway. }\end{array}$ \\
\hline
\end{tabular}

Source: [47]

In general terms, the devices used in a Nano-network are not linked to a single user or to a specific network. They can be implemented in Nano-networks of different areas, as evidenced in the following image, where a Nano-network and other corporate network architecture is located. 

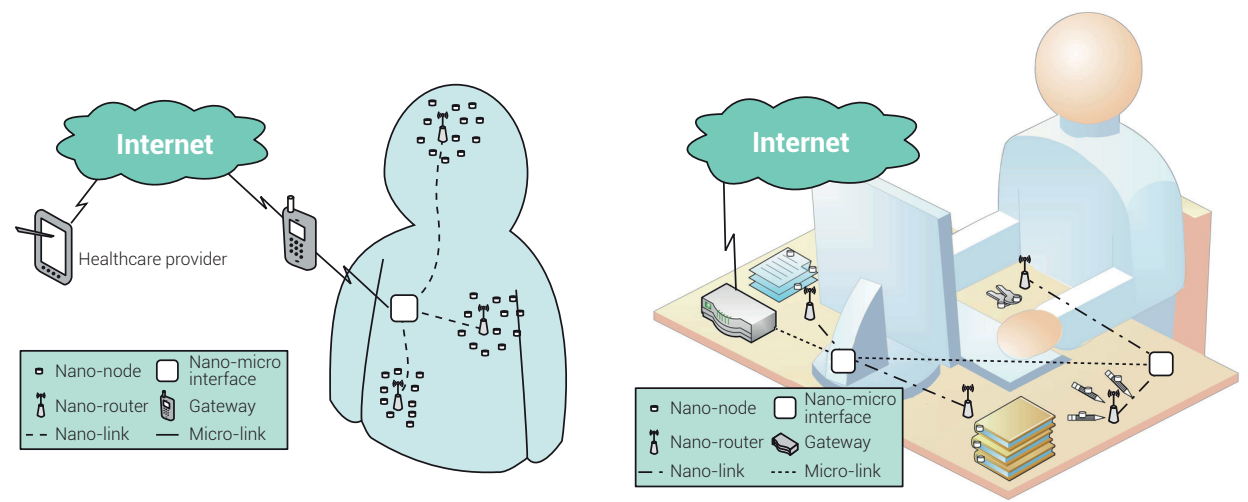

Figure 5. Architecture of a Nano-Network.

Source: [18]

\subsection{Nano-communication}

There are several challenges to developing Nano-machines and although fully functional and effective Nano-machines have not been manufactured to date, there are several solutions that have been prototyped and tested [48]. The connectivity between the Nano-devices leads to the idea of Nano-networks, which presents the definition of Nano-communication. Nano-communication will expand the capabilities of Nano-devices to promote their features and expand the range of their applications. One of the promising techniques for the exchange of data between Nano-devices is electromagnetic communication in the terahertz band. In this case, the electromagnetic wave is the carrier and its properties such as amplitude, phase and delay are used to encode and decode information [49]. The possibility of electromagnetic communication is studied based on the fact that the terahertz band can be used as the operational frequency range for future electromagnetic Nano-transceivers, thanks in part to new emerging materials such as Carbon Nanotubes and Graphene [48]. These materials are defined as very strong, thin, light and highly flexible, in addition to having very good driving properties with very high electron mobility. These unique properties allow the development of Nano-processors, Nano-memories, Nano-batteries, and Nano-sensors, which are the main building blocks for manufacturing fully operational Nano-machines [48].

The development of these new materials, which can operate at THz frequencies, allows injecting nanodevices into the human body. One of the emerging research areas is the analysis of the propagation of terahertz electromagnetic waves through tissues to develop some diagnostic tools for the early detection and treatment of tumors [49]. 


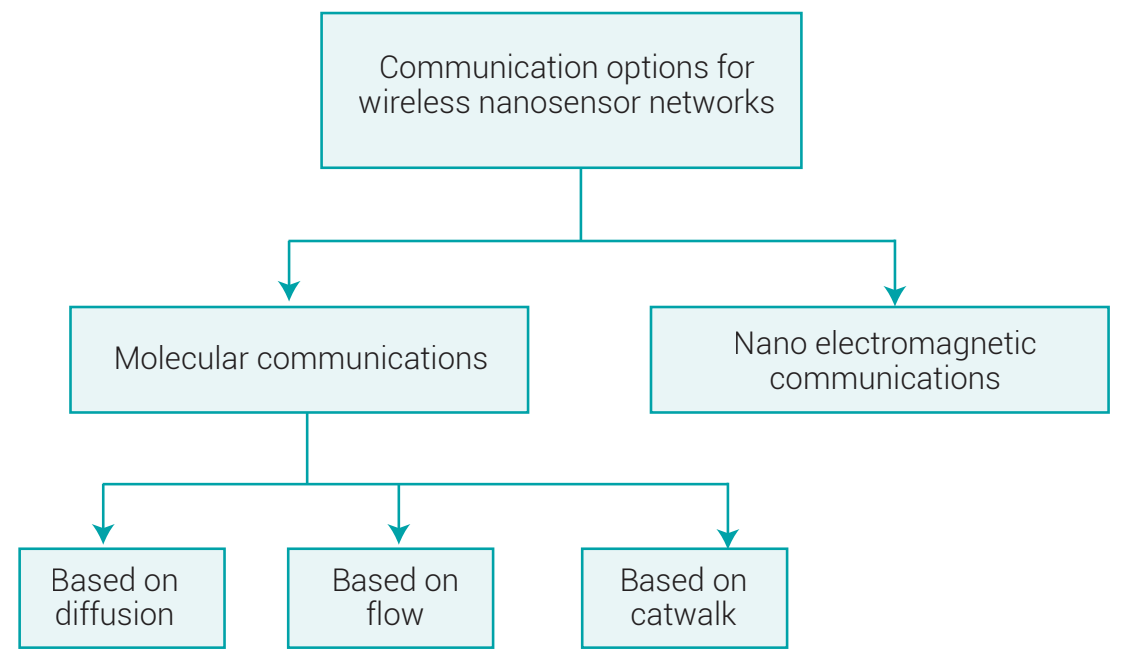

Figure 6. Nano-communication.

Source: [18]

Nano-network can be driven by capabilities provided by additional technologies to be able to organize and optimize the behavior of the Nano-devices [50]. Therefore, in order to make a Nano-network controllable on a large scale, a hierarchical architecture becomes necessary to be able to administer the Nano-devices and execute the calculations and complex operations externally. In addition, a bottom-up layer architecture can be used to explain how the performance requirements of the Nano-networks have been solved, i.e. the functionalities of the physical layer (modulation, coding, and transmission), the link layer data (access control to the medium, error control) and the network layer (information forwarding, software-defined networks, IOT).

\subsection{Modeling of channels for Nano-Devices}

To fully exploit the potential of the Nano-devices, knowledge of the propagation of the electromagnetic waveform and the channel model are necessary to build a reliable and optimized Nano-communication system. The terahertz band channel supports transmission at very high bit rates (up to 2 Terabits per second ), but at very short distances (below one meter) [51].

A unique channel model was presented in [52], where Jornet et al. developed a new channel model for terahertz band communications and showed how the absorption of several molecules in the medium attenuates and distorts the traveling waves and introduces Gaussian color noise. In [53], Jornet et al. described the coding of activation and deactivation of the time division of the frequency division 
(RD TS-OOK), which is a new modulation and access to the channel. This mechanism for Nano-devices is based on the asynchronous exchange of femtosecond pulses, that are transmitted after an on-off modulation over time. A logical "1" is transmitted through the use of a femtosecond pulse and a logical " 0 " is transmitted as silence; so the Nano-device remains silent when a logical zero is transmitted. An On-Off Keying (OOK) modulation is chosen instead of a binary Pulse Amplitude Modulation (PAM) or Pulse Position Modulation (PPM), due to the particular behavior of the molecular absorption noise. The time between transmissions is fixed and longer than the duration of the pulse so that several users can share the channel without affecting each other, with a very low probability of collision between pulses [54]. Due to the size and energy limitations of the Nano-devices, it is not possible to generate a high-power carrier signal at the Nano-level with the terahertz frequencies. As a result, classic communication paradigms based on the transmission of continuous signals cannot be used, therefore, very short pulses can be generated but they can be irradiated efficiently at the Nano-scale. In particular, the femtosecond pulses, which have their main frequency components in the terahertz band, are being used in several Nano-scale applications, such as Nano-scale spectroscopy and biological imaging [53].

\subsection{Medium access control}

In traditional communication networks, the access layer is mainly used due to the limited available bandwidth, which forces the nodes to compete on the channel or to follow the time programming schemes. In Nano-networks, the THz band channel provides a large bandwidth, which results in pretty high bit rates, really short transmission times and minimal collision probability [49]. Despite the low transmission power of the Nano-transceivers, the high loss of trajectory in the $\mathrm{THz}$ channel and the limited energy of the Nano-machines, the use of the MAC protocols are mandatory to regulate the behavior of the link, organize the access to the channel and coordinate the transmissions between the Nano-machines [49].

In [53], Jornet et al. proposed the MAC-Aware Physical Layer Protocol for Electromagnetic Nano-networks (PHLAME). This protocol was built on the basis of a new pulse communication scheme for Nano-devices, where the Nano-transmitter and receiver have selected the optimal communication parameters, and the channel coding scheme, which maximizes the probability of decoding successful messages. The protocol was built on RD TS-OOK and was divided into two stages, the stage of the exchange process and the stage of the data transmission process [53]. The intent of the recognition process is to allow a receiver to coordinate multiple simultaneous 
transmissions. In addition, it helps with the selection of the speed of transmission symbols and the coding scheme of the channel, which makes the transmission of data more reliable. First, when a Nano-device needs to send a message, it generates a transmission request packet which contains the synchronization trailer, the transmitter identification, the identification of the receiver, the identification of the packet, the transmission data symbol speed and the error detection code. The strength of the TS-OOK RD against collisions increases when different Nano-devices transmit at different speeds. In PHLAME, each transmitting node randomly selects a symbol rate from a set of rates, which has been shown to minimize the probability of collisions [53].

\section{PURPOSED MODEL: MANAGEMENT SYSTEM OF ALARMS IN A NETWORK OF NANO-SENSORS}

For this research, a theoretical prototype is proposed, which allows communication between the Nano-sensor network and a system that generates alerts and notifications, either for final clients, for a physician or for users who are investigating the implementation of what is proposed in this document. The management systems require a robust architecture in terms of the network layer and data link. In this article we propose one of the solutions commonly used in the communications industry called Tivoli Netcool that belongs to an IBM suite [55]. This software is for private use and may be a limitation for researchers, however, the use of Nagios and Pandora as a free alternative [56] [57] has also been proposed. These managers have a similar architecture for the management of alarms in a network. All three are compatible with the interpretation of SNMP traps although the IBM suite supports other standards for sending traps such as CORBA [58].

Within a Nano-scale network, as seen in its communication architecture, transmission devices are implemented between the Nano-machines that generate data frames containing the Nano-sensors through protocols such as OpenFlow. This structures the communication between the control and the plane's data from compatible network devices [59]. This architecture is compatible with a set of programming interfaces that implement common network services, including routing, multicasting, security, bandwidth management, traffic engineering, quality of service and storage optimization [60]. Sending data frames, called traps, is done through gateways or, what the alarm managers call probes. These probes are communication interfaces that implement a protocol or a standard that will then be interpreted by each manager 
through the use of rules. The rules are a mapping of the traps that enter the data collection layer [58]. Once these rules have been set, the traps become classified as alerts and are ready to be stored in the aggregation layer and in a database [61]. A critical filter of alarms has already been generated in the visualization layer and these can be observed in an application where the respective treatment is carried out [62] [61]. In this way, the management of alarms generated by the Nano-sensors is carried out.

In the case of alerts and notifications to users, the Pandora and Nagios software [63] integrate a notification module within the same application where you must configure which alerts should be notified and to whom they are directed [57]. In the case of Tivoli, you must use an event or alert correlation generator called Tivoli Impact [64]. This correlator makes use of policies and a programming language called IPL. It is used to correlate alerts, classify them, enrich them with additional information from a base data (such as the location of a person or the Nano-sensors, address of residence etc.), and within these policies are generated messages or emails for end users or those interested in receiving such alerts.

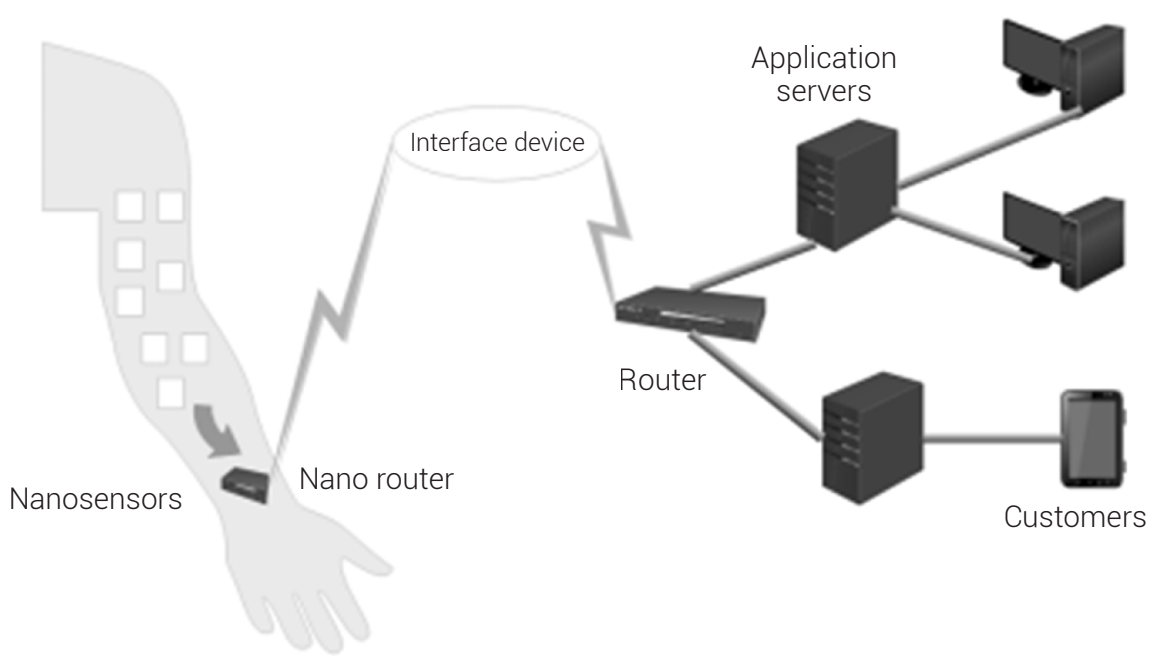

Figure 7. General structure of the solution.

Source: own work

\section{FUTURE SCOPE}

The future of Nano-networks is projected as one of the fields of research and subsequent applicability with more potential for humanity, but to achieve this potential, some problems must be evaluated and worked on, such as communication between devices, content management, security and privacy, the composition of the service, and discovery [65]. 
When facing some of the advances and improvements, new service-oriented architectures must be proposed to ensure that Nano-sensors and Nano-networks are capable of storing vast quantities of information [65], which will encourage the use of these devices in areas such as [46]:

- Biomedicine in drug administration systems, control of health within the body, mechanisms to support the immune system and implants of artificial bio-hybrids.

- Industrial and consumer goods in the development of materials and fabrics with intelligent functionality, new manufacturing processes and distributed quality control procedures, food and water quality control systems.

- Environmental networks of biological and chemical Nano-sensors for the control of pollution, assistance in biodegradation and control of animals and biodiversity.

- Military in terms of nuclear, biological and chemical defenses and nano-functional equipment.

This raises a wide field of action with a very good future ahead, helping humanity in the areas mentioned aboce. It is also important to mention that the promotion of these technologies will also require the generation of more rigorous and accurate policies regarding the administration and privacy of information. This is because the IONT uses more refined and accurate techniques for the accumulation of information than the ones established or allowed by the IoT [66], which generates a need for greater control of the entities that administer these devices for the common population.

\section{CONCLUSIONS}

The number of cases of Diabetes mellitus are expected to rise over the coming years in Colombia, especially amongst younger age groups. This is due to the directly proportional increase of overweight inhabitants throughout the territory. Therefore, it is necessary to research more techniques and treatments to produce an improvement in the quality of life of those affected by this disease.

The development of Nano-networks for medical use could save lives and make a big contribution to the detection of problems in time. These networks that have devices with very limited operational capabilities need different strategies with a new paradigm of communication. In this document, we propose a communication prototype for Nano-networks and an alarm management system that 
combines a software-defined network, Internet of Nano-things and virtualization of network functions.

In this article a theoretical prototype has been presented. Its functionality, along with the mentioned programs for the management of alarms, has a fundamental challenge in the form of the generation of data frames through compatible protocols or services. Although the virtualization of network functions is proposed to facilitate communication between network devices, at present the development of Nanodevices is still limited. Therefore, it is expected to evolve alongside relevant hardware advances, eventually leading to the generation of real Nano-network prototypes for medical use.

In the near future, it is expected that prototypes will be implemented in real or production environments that allow measurements and studies to be performed on the impact of this new technology, expanding the normativity in front of the new communication paradigm in Nano-scale and the viability regarding its use in biomedicine or other related branches.

\section{References}

[1] Organización Mundial de la Salud, Diabetes: cifras y datos, pp. 1, 2018. [Online]. Available: http://www.who.int/es/news-room/fact-sheets/detail/diabetes.

[2] "Guías ALAD de diagnóstico, control y tratamiento de la Diabetes Mellitus Tipo 2," Revista de la Asociación Latinoamericana de Diabetes, pp. 28-29, 2013. [Online]. Available: https:// www.paho.org/hq/dmdocuments/2012/OPS-Guias-ALAD-diagnostico-control-tratamiento -2009.pdf

[3] S. Boudina and E. D. Abel, "Diabetic cardiomyopathy revisited," Circulation, vol. 115, no. 25, pp. 3213-3223, Jun. 2007. [Online]. doi: 10.1161/circulationaha.106.679597

[4] Organización Panamericana de la Salud (OPS), Editorial Panamericana, pp. 1, 2008.

[5] D. R. Whiting, L. Guariguata, C. Weil and J. Shaw, "IDF Diabetes Atlas: Global estimates of the prevalence of diabetes for 2011 and 2030," Diabetes Research and Clinical Practice, vol. 94, no.3, pp. 311-321. [Online]. doi: https://doi.org/10.1016/j.diabres.2011.10.029 
[6] "IDF Diabetes Atlas 7th Edition (2015)," International Diabetes Federation, pp. 1, diciembre, 2018. [Online]. Available: https://www.idf.org/e-library/epidemiology-research/diabetesatlas/13-diabetes-atlas-seventh-edition.html.

[7] "Departamento Administrativo Nacional de Estadísticas. Proyecciones de población. 2005 2016", pp. 1, diciembre, 2018. [Online]. Available: http://www.dane.gov.co/index.php/ estadisticas-por-tema/demografia-y-poblacion/proyecciones-de-poblacion

[8] P. Aschner, "Epidemiología de la diabetes en Colombia," Avances en diabetología, vol. 26, no 2, pp. 71-134, abril. 2010. [Online]. Available: http://www.elsevier.es/es-revista-avances-diabetologia-326-articulo-epidemiologia-diabetes-colombia-S1134323010620054. doi: 10.1016V/s1134-3230(10)62005-4

[9] P. López, C.Calderón, J. Castillo, I. Escobar, E. Melgarejo, and G. Parra, “Prediabetes in Colombia: Expert Consensus," Colombia MéDica, vol. 48, no. 4, pp. 191-203, 2017. [Online]. Available: http://colombiamedica.univalle.edu.co/index.php/comedica/article/view/3662/3455. doi: $10.25100 \bigvee / c m . v 48 i 4.3662$

[10] J. Ojeda González y E. Dávila, “Valoración anestésica del paciente diabético," MediSur, vol. 10, no. 3. pp. 245-258, mayo-jun. 2012. [Online]. Available: http://scielo.sld.cu/scielo.php?script=sci_arttext\&pid=S1727-897X2012000300014. ISSN: 1727-897X

[11] M. Feldgen, "Internet de las Cosas y los ciudadanos," Tecnología y Sociedad, vol. 7, pp. 27-48, 2018.

[12] S. C. Chen, H. Xu, D. Liu, B. Hu and H. Wang, "A Vision of IoT: Applications, Challenges, and Opportunities with China Perspective," IEEE Internet of Things Journal, vol. 1, no. 4, pp. 349359, 2014. [Online]. doi: 10.1109Vjiot.2014.2337336

[13] K. Rose, S. Eldridge y L. Chapin, "La Internet De Las Cosas - Una Breve Reseña," Internet Society, pp. 1, octubre. 2015. [Online]. Available: https://www.internetsociety.org/wp-content/uploads/2017/09/report-InternetOfThings-20160817-es-1.pdf

[14] Área Tecnología, “Internet de las Cosas,” pp. 1, marzo. 2019. [Online]. Available: https://www. areatecnologia.com/nuevas-tecnologias/internet-de-las-cosas.html

[15] M. Maksimović, "The roles of Nanotechnology and Internet of Nano things in healthcare transformation," TecnoLógicas, vol. 20, no. 40, pp. 139-153, Dec. 2017. [Online]. Available: http://www.scielo.org.co/scielo.php?script=sci_arttext\&pid=S0123-77992017000300011\&lng=en\&tlng=en. doi: $10.22430 \backslash / 22565337.720$ 
[16] D. Ezquerra, À. Fabregas, M. Toro y J. Borrell, "Un Enfoque Tolerante a Interrupciones para la Seguridad de la Internet de las Cosas," RECSI, pp. 1, Sept. 2014. [Online]. Available: https:// web.ua.es/es/recsi2014/documentos/papers/un-enforque-tolerante-a-interrupciones-para-la-seguridad-de-la-internet-de-las-cosas.pdf. ISBN: 978-84-9717-323-0

[17] P. Raut y N. Sarwade, "Study of environmental effects on the connectivity of molecular communication based Internet of Nano things," 2016 International Conference on Wireless Communications, Signal Processing and Networking (WiSPNET), pp. 1123-1128. [Online]. doi: 10.1109\/wispnet.2016.7566311

[18] A. Cruz y A. Mainor, "Internet de las nano-cosas: estado del arte y tendencias," Especialista en Redes y Seguridad. Buenos Aires, Argentina: Universidad Nacional De La Plata Facultad De Informática. p. 1, 2017.

[19] S. J. Lee, C. Jung. K. Choi, and S. Kim, "Design of Wireless Nanosensor Networks for Intrabody Application," International Journal of Distributed Sensor Networks. pp. 1-12, Jul. 2015. [Online]. Available: https://journals.sagepub.com/doi/10.1155/2015/176761. doi: $10.1155 / 2015 / 176761$

[20] I. F. Akyildiz, M. Pierobon, S. Balasubramaniam, and Y. Koucheryavy, "The internet of Bio-Nano things," Nano Commun, vol. 53, pp. 32 - 40, 2015. [Online]. doi: 10.1109 \mcom.2015.7060516

[21] B. Bushan, "Springer Handbook of Nanotechnology," Springer Handbooks, pp. 1, 2010. doi: 10.1007 \978-3-642-02525-9

[22] T. Nakano, A.W. Eckford, and T. Haraguchi, "Molecular communication". UK: Cambridge Press, pp. 1, 2013. [Online]. doi: 10.1017\/cbo9781139149693.005.

[23] T. Nakano, M. Moore, Y. Okaie, A. Enomoto, and T. Suda, "Swarming biological nanomachines through molecular communication for targeted drug delivery," 6th International Conference on Soft Computing and Intelligent Systems/13th International Symposium on Advanced Intelligent Systems (SCIS- ISIS 2012), pp. 2317-2320, 2012.

[24] K.Cai, A. Z. Wang, L. Yin, and J. Cheng, "Bio-nano interface: the impact of biological environment on nanomaterials and their delivery properties," Journal of Controlled Release, vol. 263, pp. 211-222. 2017. [Online]. Available: https://www.sciencedirect.com/science/article/pii/ S0168365916305272. doi: 10.1016/j.jconrel.2016.11.034 
[25] J. P. Bermeo y C. F. Sánchez, "Modelamiento y simulación de la contracción muscular mediante la estimulación magnética externa,” p. 21, 2017. [Online]. Available: https://dspace. ups.edu.ec/bitstream/123456789/14943/1/UPS-CT007369.pdf

[26] J. A. Martín, “La grandeza de lo pequeño", El mundo, pp. 1, enero. 2019. [Online]. Available: https://www.elmundo.es/elmundo/2013/05/27/nanotecnologia/1369659640.html

[27] J. Martin, C. Briones, E. Casero y P. Serena, "Nano-ciencia y Nano-tecnología: Entre la ciencia ficción del presente y la tecnología del futuro. Publicación de la Fundación Española para la Ciencia y la Tecnología," Cultura científica, pp. 23, 2009.

[28] Euroresidentes, “Qué es la Nanotecnología?," p. 1, enero, 2019. [Online]. Available: https:// www.euroresidentes.com/futuro/nanotecnologia/nanotecnologia_que_es.htm

[29] A. Hernandez, "Breve estudio de las implicaciones sociales de la nanociencia y la nanotecnología," Razón y Palabra, no. 68, pp. 1, 2009.

[30] N. Takeuchi y M. E. Mora Ramos, "Divulgación y formación en nanotecnología en México," Mundo Nano. Revista Interdisciplinaria en Nanociencia y Nanotecnología, vol. 4, no. 2, pp. 1, julio-diciembre, 2011.

[31] G. N. Calle, "Nanotecnología Conceptos Generales," RITS, no. 5, pp. 7-9, nov. 2010.

[32] H. Bouwmeester, S. Dekkers, M. Noordam, W. Hagens, A. Bulder, C. Heer, S. E. Ten, S. W. Wijnhoven, H. J. Marvin, and A. J. Sips, "Review of health safety aspects of nanotechnologies in food production," Regul Toxicol Pharmacol, vol. 53, no. 1, pp. 52-62, 2009. [Online]. doi: 10.1016 Vj.yrtph.2008.10.008

[33] L. M. Lechuga, "Nanomedicina: aplicación de la nanotecnología en la salud," Biotecnología Aplicada a la Salud Humana, no. 9, pp. 1, 2011.

[34] H. Pastrana y A. Avila, "Nanomedicina: Estado del arte," Revista de Ingeniería Universidad de los Andes, no. 25, pp. 60-69, mayo, 2007.

[35] S. Fedorovich, A. Alekseenko, and T. Waseem, "Are synapses targets of nanoparticles?" Biochem Soc Trans., vol. 38, no. 2, pp. 536-538, 2010. [Online]. doi: 10.1042 Vbst0380536

[36] N. Pájaro, J. O. Verbel, y J. Redondo, "Nanotecnología aplicada a la medicina," Revista Científica Guillermo de Ockham, no. 11. pp. 125-133, junio, 2013. [Online]. doi: 10.21500 /22563202.606 
[37] P. Boisseau and B. Loubatonb, "Nanomedicine, nanotechnology in medicine," CR Physique, vol. 12, no. 7, pp. 620-636, 2011.

[38] L. Lechuga y C. M., "Nanotecnología: avances diagnósticos y terapeúticos," Revista madrid, no. 35, p. 1, 2006.

[39] R. Muñoz, Nanomedicina y sensores: alcance de la nanotecnología para el monitoreo y control de la glucosa en pacientes con diabetes, Colombia: Universidad Nacional, p. 1.

[40] S. Calechman, "Finding the Molecular Needle in the Haystack," MIT, p. 1, septiembre. 2018. [Online]. doi: 10.1126/science.8016654

[41] “Nanosensores biológicos," Euroresidentes, p. 1, diciembre. 2018, [En línea]. Disponible en: https://www.euroresidentes.com/tecnologia/nanotecnologia/nanosensores-biolgicos

[42] K. Stylios, V. Giannoudis, and T. Wan, "Applications of nanotechnologies in medical practice," Injury, Int J Care Inju., vol. 36, no. 4, pp 6-13, 2005. [Online]. doi: 10.1016Vj.injury.2005.10.011

[43] S. Sahoo, S. Parveen and J. Panda, "The present and future of nanotechnology in human health Care," Nanomedicine: NBM., vol. 3, no. 1, pp. 20-31, 2007. [Online]. doi: 10.1016Vj. nano.2006.11.008

[44] J. Pickup, Z. Zhi, F. Khan, T. Saxl and D. Birch, "Nanomedicine and its potential in diabetes research and practice," Diabetes Metab. Res Rev., vol. 24, no. 8, pp. 604-610, 2008.

[45] A. Galal and X. Hesselbach, "Nano-networks communication architecture: Modeling and functions," Nano Communication Networks, vol. 17, pp. 45-62, septiembre. 20018. [Online]. doi: 10.1016/j.nancom.2018.07.001

[46] I. F. Akyildiz, J. M. Jornet, and M. Pierobon, "Nanonetworks: A new frontier in communications Commun," ACM, vol 54, no 11, pp. 84-89, 2011. doi: 10.1145\2018396.2018417

[47] K. Dabhi and A. Maheta, "Internet of Nano Things-The Next Big Thing," IJESC, vol. 7, no 4, pp, 10602-10604, 2017.

[48] J. M. Jornet Montana, "Fundamentals of electromagnetic nanonetworks in the terahertz band," Doctoral dissertation, Georgia Institute of Technology, 2013. [Online]. doi: $10.1561 \bigvee 1300000045$

[49] Q. H. Abbasi, K. Yang, N. Chopra, J. M. Jornet, N. A.Abuali, K. A. Qaraqe, and A. Alomainy, "Nanocommunication for biomedical applications: A review on the state-of-the-art from physical 
layers to novel networking concepts," IEEE Access, vol 4, pp. 3920-3935, 2016. [Online]. doi: 10.1109\/access.2016.2593582

[50] S. Balasubramaniam and J. Kangasharju, "Realizing the internet of nano things: Challenges, solutions, and applications," Computer, vol. 46, no. 2, pp. 62-68, 2013. [Online]. doi: 10.1109V mc.2012.389

[51] P. Wang, J. M. Jornet, M. A. Malik, N. Akkari, and I. F. Akyildiz, "Energy and spectrum-aware MAC protocol for perpetual wireless nanosensor networks in the Terahertz Band," Ad Hoc Networks, vol 11, no 8, pp. 2541-2555, 2013.[Online]. doi: 10.1016/j.adhoc.2013.07.002

[52] J. M. Jornet and I. F. Akyildiz, "Channel modeling and capacity analysis for electromagnetic wireless nanonetworks in the terahertz band," IEEE Transactions on Wireless Communications, vol 10, no 10l, pp. 3211-3221, 2011. [Online]. doi: 10.1109/twc.2011.081011.100545

[53] J. M. Jornet, J. C. Pujol, and J. S. Pareta. Phlame, "A physical layer aware mac protocol for electromagnetic nanonetworks in the terahertz band," Nano Communication Networks, vol 3 no 1, pp. 74-81, 2012. [Online]. doi: 10.1016Vj.nancom.2012.01.006

[54] J. M. Jornet, and I. F. Akyildiz, "Information capacity of pulse-based wireless nanosensor networks. In Sensor, Mesh and Ad Hoc Communications and Networks (SECON). 2011," 8th Annual IEEE Communications Society Conference, pp. 80-88, 2011.

[55] J, M. Vizcaya, Soluciones de gestión de redes, pp. 19-24, abril. 2016. [Online]. Available: $\mathrm{ftp}: / /$ public.dhe.ibm.com/la/documents/swg/es/cross/events/Gestion_de_redes_en_un_ entorno_virtualizado-Esta_lista_su_infraestructura_de_TI.pdf

[56] C. Vicente, Servicios de red: gestión de traps SNMP, p. 1, 2018. [Online]. Available: https://nsrc. org/workshops/2008/walc/presentaciones/gestion_traps.pdf

[57] PANDORA FMS, Documentation: Guía de administración Pandora FMS 7.0 NG Versión, pp. 1, 2018. [Online]. Available: https://wiki.pandorafms.com/index.php?title=Pandora :Documentation_es:Arquitectura

[58] IBM, Guía de analizadores y pasarelas Tivoli Netcool/OMNIbus versión 8.1, pp. 1, 2018 [Online]. Available: https://www.ibm.com/support/knowledgecenter/es/SSSHTQ_8.1.0/com.ibm. netcool_OMNIbus.doc_8.1.0/omn_pdf_prgw_master.pdf?view=kc

[59] D. A. Maldonado, "Diseño e implementación de una aplicación de red bajo la arquitectura SDN," Master's thesis, Facultad de Ingeniería, pp. 1, 2018. 
[60] Fundation, O. N., Software-defined networking, The new norm for networks. ONF White Paper, vol 2, pp. 2-6, 2012

[61] IBM, Documentation: Quick Start Guide Netcool/OMNIbus versión 8.1, pp. 1, 2018. [Online]. Available: ftp://ftp.software.ibm.com/software/tivoli/Netcool/NetcoolOmnibus/library/omnibus810/CIZ6JML.pdf

[62] L. J. Calderón, Implementación de Ibm Tivoli Netcool Omnibus para la gestión de fallas de una red LTE en una solución de gestión unificada de servicios de telecomunicaciones, p. 1, 2018.

[63] Nagios, Documentation: Overview, pp. 1, 2018. [Online]. Available: https://www.nagios.org/ about/

[64] IBM, Documentation: Quick Start Guide Netcool/Impact versión 7.1, pp. 1, 2018. [Online]. Available: https://www.ibm.com/support/knowledgecenter/SSSHYH_7.1.0/com.ibm.netco olimpact.doc_7.1/QuickStartGuide.pdf?view=kc

[65] A. Nayyar, V. Puri, and D. Le, "Internet of nano things (IoNT): Next evolutionary step in nanotechnology. Nanosci," Nanotechnol, vol. 7, no 1, pp. 4-8, 2017. [Online]. Available: http://article. sapub.org/10.5923.j.nn.20170701.02.html\#Ref. doi: 10.5923/j.nn.20170701.02

[66] Y. S. Mezaal, L. N Yousif, Z.j. Abdulkareem, H. A. Hussein and S. K. Kgaleel, "Review about effects of IOT and Nano-technology techniques in the development of IONT in wireless systems," International Journal of Engineering \& Technology, vol. 7, no. 4, pp. 3602-3606. 2018. [Online]. Available: https://www.sciencepubco.com/index.php/ijet/article/view/21741/10418 